\title{
PENGARUH PENDEKATAN MATEMATIKA REALISTIK TERHADAP DISPOSISI MATEMATIS SISWA
}

\section{(THE INFLUENCE OF REALISTIC MATHEMATICAL APPROACHES TO STUDENTS' MATHEMATICAL DISPOSITION)}

\author{
Rayinda Aseti Prafianti ${ }^{1}$ \\ 1 Universitas Islam Lamongan, rayindaaseti@unisla.ac.id
}

\begin{abstract}
Abstrak. Penelitian ini bertujuan untuk menelaah perbedaan disposisi matematis siswa yang memperoleh pembelajaran dengan pendekatan matematika realistik dan siswa yang memperoleh pembelajaran dengan pendekatan konvensional. Dalam penelitian ini metode yang digunakan adalah metode kuantitatif yaitu Quasi Experimental Design dengan bentuk postresponse only, nonequivalent control group design. Penelitian ini dilaksanakan disalah satu SMP Negeri di Lembang Jawa Barat. Data diperoleh dari non-tes berupa angket skala disposisi matematis. Hasil penelitian menunjukkan bahwa, disposisi matematis siswa yang memperoleh pembelajaran dengan pendekatan matematika realistik lebih tinggi secara signifikan daripada siswa yang memperoleh pembelajaran dengan pendekatan konvensional.
\end{abstract}

Kata kunci: Pendekatan Matematika Realistik, Disposisi Matematis

\begin{abstract}
This research aims to examine the differences students' mathematical disposition using realistic mathematical approach and conventional approach. This research used quantitative method that was quasi experimental design with postresponse only, nonequivalent control group design. This research was conducted in one of junior high school in Lembang, West Java. Data were obtained from non-test, mathematical disposition questionnaire. The results showed that the mathematical disposition of students who obtained learning using realistic mathematical approach were significantly higher than students who obtained learning using conventional approach.
\end{abstract}

Keywords: Realistic Mathematics Education, Mathematical Disposition 


\section{PENDAHULUAN}

Prestasi belajar siswa tidak hanya dipengaruhi oleh kemampuan kognitif, tetapi juga dipengaruhi oleh kemampuan afektif. Hal ini disampaikan oleh Putra, Budiyono, \& Slamet (2017), sikap siswa terhadap matematika merupakan konsep penting dalam proses belajar matematika. Kemampuan afektif yang mempengaruhi prestasi siswa dalam matematika salah satunya adalah disposisi matematis. Hal ini diperkuat dengan pernyataan Kilpatrick (2001) yang menyatakan bahwa disposisi matematis merupakan faktor utama dalam menentukan kesuksesan belajar. Disposisi siswa terhadap matematika terwujud melalui sikap dan tindakan dalam memilih pendekatan menyelesaikan tugas. Apakah dilakukan dengan percaya diri, keingintahuan mencari alternatif, tekun, dan tertantang serta kecenderungan siswa merefleksi cara berpikir yang dilakukannya.

NCTM (1989) menyatakan disposisi matematis adalah keterkaitan dan apresiasi terhadap matematika yaitu suatu kecenderungan untuk berpikir dan bertindak dengan cara yang positif. Menurut Maxwell (2001), disposisi terdiri dari (1) inclination (kecenderungan), yaitu bagaimana sikap siswa terhadap tugas-tugas; (2) sensitivity (kepekaan), yaitu bagaimana kesiapan siswa dalam menghadapi tugas; dan (3) ability (kemampuan), yaitu bagaimana siswa fokus untuk menyelesaikan tugas secara lengkap; dan (4) enjoyment (kesenangan), yaitu bagaimana tingkah laku siswa dalam menyelesaikan tugas. Sedangkan menurut Sumarmo (2006), disposisi matematis adalah keinginan, kesadaran, dan dedikasi yang kuat pada diri siswa untuk belajar matematika dan melaksanakan berbagai kegiatan matematika. Dari ketiga definisi diatas, disposisi matematis didefinisikan sebagai keterkaitan dan apresiasi terhadap matematika yaitu suatu keinginan, kesadaran, dan dedikasi yang kuat pada diri siswa untuk belajar matematika dan melaksanakan berbagai kegiatan matematika.

Lestari dan Yudhanegara (2015) menyatakan untuk mengukur disposisi matematis siswa indikator yang digunakan adalah sebagai berikut: 1) rasa percaya diri dalam menggunakan matematika, 2) fleksibilitas dalam menyelidiki gagasan matematis dan berusaha mencari metode alternatif dalam menyelesaikan masalah, 3) Tekun mengerjakan tugas matematika, 4) memiliki minat, rasa ingin tahu, dan daya temu dalam melakukan tugas matematika, 5) memonitor dan merefleksikan performance yang dilakukan, 6) menilai aplikasi matematika ke situasi lain dalam matematika dan pengalaman sehari-hari, 7) mengapresiasi peran matematika dalam kultur dan nilai matematika sebagai alat dan sebagai bahasa.

Salah satu yang mempengaruhi disposisi matematis siswa adalah lingkungan belajar. Guru hendaknya menciptakan lingkungan belajar yang nyaman dan menyenangkan karena disposisi matematis siswa cenderung meningkat jika siswa semangat dalam mengikuti kegiatan

37 | Jurnal Pendidikan Matematika dan Matematika Vol. I No. 01 Februari 2019 
belajar mengajar di kelas. Cara guru mengajar, model atau pendekatan yang digunakan dapat mempengaruhi semangat siswa dalam belajar. Ada banyak pendekatan pembelajaran, pendekatan pembelajaran yang dirasa dapat mempengaruhi disposisi matematis siswa adalah pendekatan matematika realistik. Pendekatan matematika realistik dirasa efektif untuk mempengaruhi disposisi matematis karena berpusat pada siswa dan menghubungkan matematika dengan kehidupan nyata. Selain itu, pendekatan matematika realistik diawali dengan masalah-masalah nyata dari kehidupan sehari-hari yang memunculkan pandangan siswa bahwa matematika sangat dekat dengan aktivitas manusia. Pandangan ini memunculkan sikap positif siswa terhadap matematika.

\section{METODE}

Penelitian dilakukan disalah satu SMP Negeri di Lembang Jawa Barat pada kelas VIII. Subjek pada penelitian ini terdiri dari dua kelas, kelas eksperimen dan kelas kontrol. Pada kelas eksperimen diterapkan pembelajaran dengan pendekatan matematika realistik sedangkan pada kelas kontrol diterapkan pembelajaran dengan pendekatan konvensional.

Dalam penelitian ini metode yang digunakan adalah metode kuantitatif yaitu Quasi Experimental Design. Desain eksperimen yang digunakan adalah postresponse only, nonequivalent control group design (Wiersma \& Jurs, 2005; Ruseffendi, 2010).

\section{HASIL DAN PEMBAHASAN}

Perbedaan disposisi matematis siswa yang memperoleh pembelajaran dengan pendekatan matematika realistik dan siswa yang memperoleh pembelajaran dengan pendekatan konvensional dianalisis dengan statistik deskriptif dan statistik inferensial. Hasil statistik deskriptif skala disposisi matematis kedua kelas disajikan dalam Tabel 1 berikut.

Tabel 1 Hasil Statistik Deskriptif Skala Disposisi Matematis

\begin{tabular}{lcc}
\hline \multirow{2}{*}{ Statistik } & \multicolumn{2}{c}{ Pembelajaran } \\
\cline { 2 - 3 } & PMR & PK \\
\hline Minimum & 56 & 50 \\
\hline Maksimum & 98 & 87 \\
\hline $\bar{x}$ & 70,60 & 66,1 \\
\hline$S$ & 10,36 & 9,64 \\
\hline
\end{tabular}

Berdasarkan Tabel 1, skor minimum disposisi matematis siswa yang memperoleh pembelajaran dengan pendekatan matematika realistik secara deskriptif lebih rendah daripada siswa yang memperoleh pembelajaran dengan pendekatan konvensional. Sebaliknya, skor maksimum skala disposisi matematis siswa yang memperoleh pembelajaran dengan pendekatan matematika realistik secara deskriptif 
lebih tinggi daripada siswa yang memperoleh pembelajaran dengan pendekatan konvensional.

Rata-rata skala disposisi matematis siswa yang memperoleh pembelajaran dengan pendekatan matematika realistik adalah 70,60 yang lebih tinggi dari rata-rata skala disposisi matematis siswa yang memperoleh pembelajaran dengan pendekatan konvensional yaitu 66,1. Selisih skor rata-rata kedua kelas berbeda tipis yaitu 4,5. Secara deskriptif, jika dilihat dari rata-rata di atas, disposisi matematis siswa yang memperoleh pembelajaran dengan pendekatan matematika realistik lebih tinggi daripada siswa yang memperoleh pembelajaran dengan pendekatan konvensional.

Skala disposisi matematis juga diuji menggunakan uji perbedaan rata-rata. Karena data skala disposisi matematis merupakan data ordinal, maka langsung digunakan uji non-parametric yaitu uji Mann-Whitney U. Hipotesis yang diuji berbunyi "Disposisi matematis siswa yang memperoleh pembelajaran dengan pendekatan matematika realistik lebih tinggi secara signifikan daripada siswa yang memperoleh pembelajaran dengan pendekatan konvensional".

Pengujian dua arah dilakukan pada taraf signifikansi $\alpha=0,05$. Kriteria pengujiannya adalah jika nilai Sig.(1-tailed) $>\alpha$ maka $\mathrm{H}_{0}$ diterima, sebaliknya jika nilai Sig.(1-tailed) $\leq \alpha$ maka $\mathrm{H}_{0}$ ditolak. Berikut disajikan hasil uji perbedaan rata-rata skala disposisi matematis siswa.

Tabel 2 Hasil Uji Perbedaan Rata-rata Skala Disposisi Matematis

\begin{tabular}{cc} 
Statistika & Angket \\
\hline Mann-Whitney $U$ & 339,000 \\
Z & $-1,643$ \\
Sig. & 0,100 \\
$\mathrm{H}_{0}$ & Ditolak
\end{tabular}

$\mathrm{H}_{0}$ : Tidak terdapat perbedaan rata-rata antar kedua kelompok

$\mathrm{H}_{1}$ : Terdapat perbedaan rata-rata antar kedua kelompok

Tabel 2 menunjukkan bahwa nilai Sig.(1-tailed)=0,05 sama dengan $\alpha=0,05$, artinya $\mathrm{H}_{0}$ ditolak. Dengan kata lain, disposisi matematis siswa yang memperoleh pembelajaran dengan pendekatan matematika realistik lebih tinggi secara signifikan daripada siswa yang memperoleh pembelajaran dengan pendekatan konvensional.

Hasil skala disposisi matematis menunjukkan bahwa rataan disposisi matematis siswa yang memperoleh pembelajaran dengan pendekatan matematika realistik lebih tinggi jika dibandingkan dengan disposisi matematis siswa yang memperoleh pembelajaran dengan pendekatan konvensional.

Jika ditinjau berdasarkan tiap indikator disposisi matematis, secara umum disposisi matematis siswa yang memperoleh pembelajaran dengan

39 | Jurnal Pendidikan Matematika dan Matematika Vol. I No. 01 Februari 2019 
Pendekatan Matematika Realistik (PMR) lebih baik daripada disposisi matematis siswa yang memperoleh pembelajaran dengan Pendekatan Konvensional (PK). Perbedaan rataan disposisi matematis siswa yang memperoleh pembelajaran dengan pendekatan matematika realistik dan disposisi matematis siswa yang memperoleh pembelajaran dengan pendekatan konvensional ditinjau dari setiap indikator dapat dilihat pada Gambar 1, Gambar 2, Gambar 3, Gambar 4, dan Gambar 5 berikut.

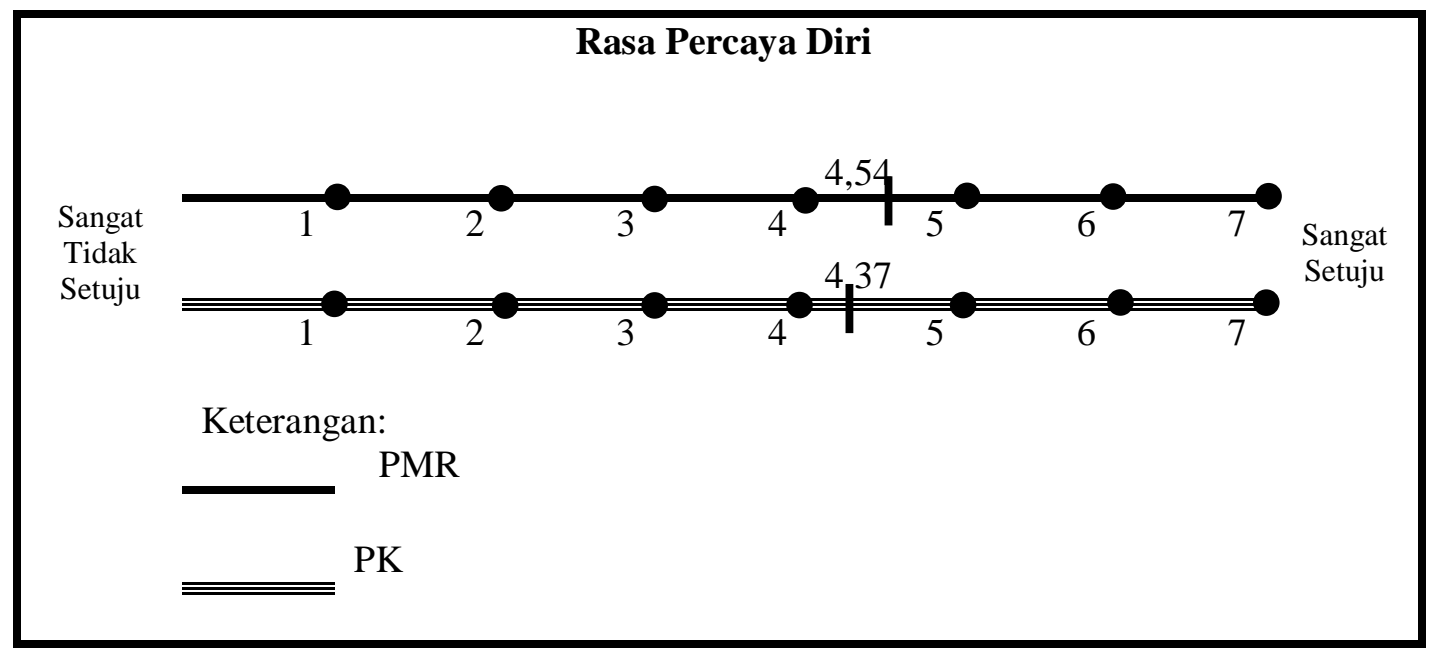

\section{Gambar 1 Disposisi Matematis Siswa Kedua Kelas Berdasarkan Indikator Rasa Percaya Diri}

Pada Gambar 1 diperoleh bahwa rasa percaya diri siswa yang memperoleh pembelajaran dengan pendekatan matematika realistik lebih tinggi yaitu 4,54 jika dibandingkan dengan rasa percaya diri siswa yang memperoleh pembelajaran dengan pendekatan konvensional, yaitu 4,37. Temuan ini didukung oleh pernyataan Bakker (2004) yang menyatakan bahwa sifat pendekatan matematika realistik yang berpusat pada siswa menjadikan siswa lebih aktif dalam kegiatan diskusi di kelas.

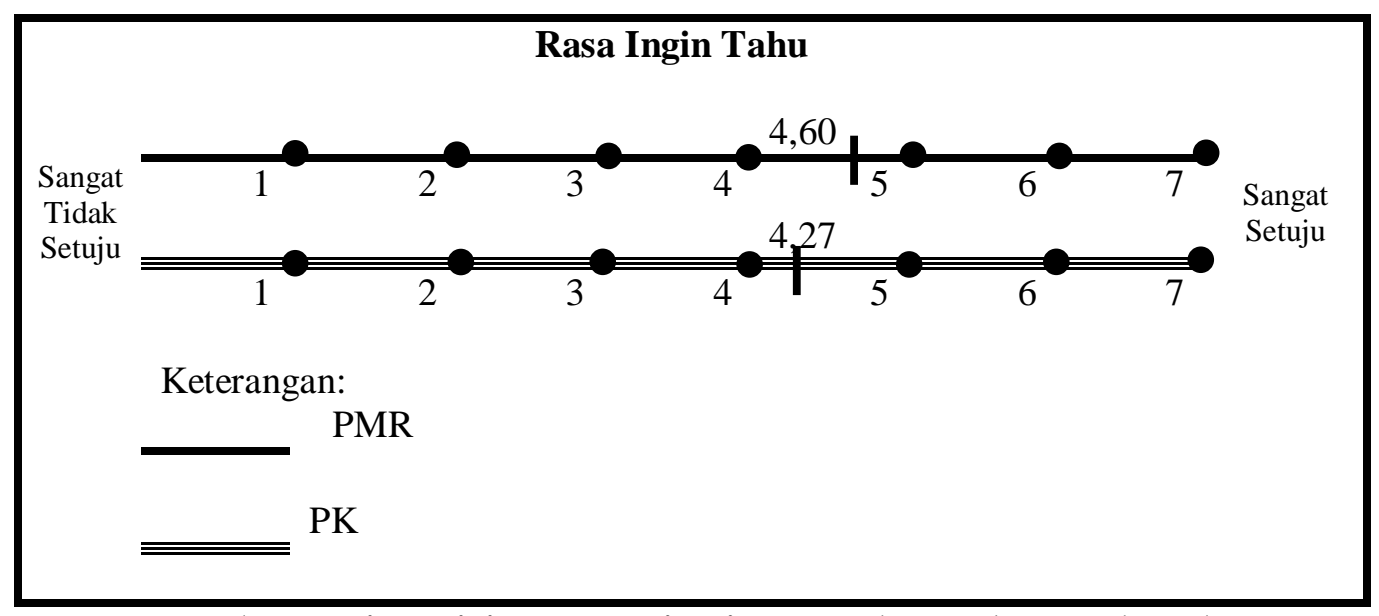

Gambar 2 Disposisi Matematis Siswa Kedua Kelas Berdasarkan Indikator Rasa Ingin Tahu 
Pada Gambar 2 diperoleh bahwa rasa ingin tahu siswa yang memperoleh pembelajaran dengan pendekatan matematika realistik lebih tinggi yaitu 4,60 jika dibandingkan dengan rasa percaya diri siswa yang memperoleh pembelajaran dengan pendekatan konvensional, yaitu 4,27. Temuan ini sejalan dengan pendapat Rahayu \& Kartono (2014) yang menyatakan bahwa aktivitas awal dari pendekatan matematika realistik dapat menstimulasi siswa untuk memiliki rasa ingin tahu yang besar sehingga berdampak pada ketekunan siswa dalam mencari solusi dari permasalahan yang disajikan.

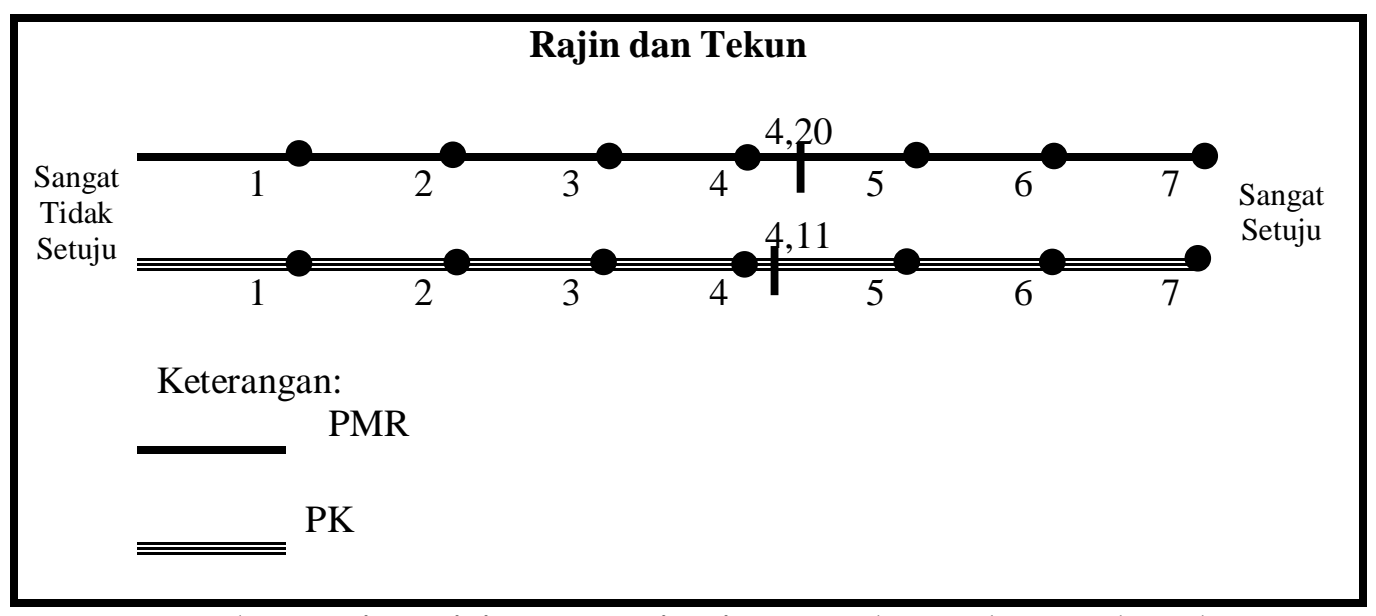

\section{Gambar 3 Disposisi Matematis Siswa Kedua Kelas Berdasarkan Indikator Rajin dan Tekun}

Pada Gambar 3 diperoleh bahwa ketekunan siswa yang memperoleh pembelajaran dengan pendekatan matematika realistik lebih tinggi yaitu 4,20 jika dibandingkan dengan rasa percaya diri siswa yang memperoleh pembelajaran dengan pendekatan konvensional, yaitu 4,11.

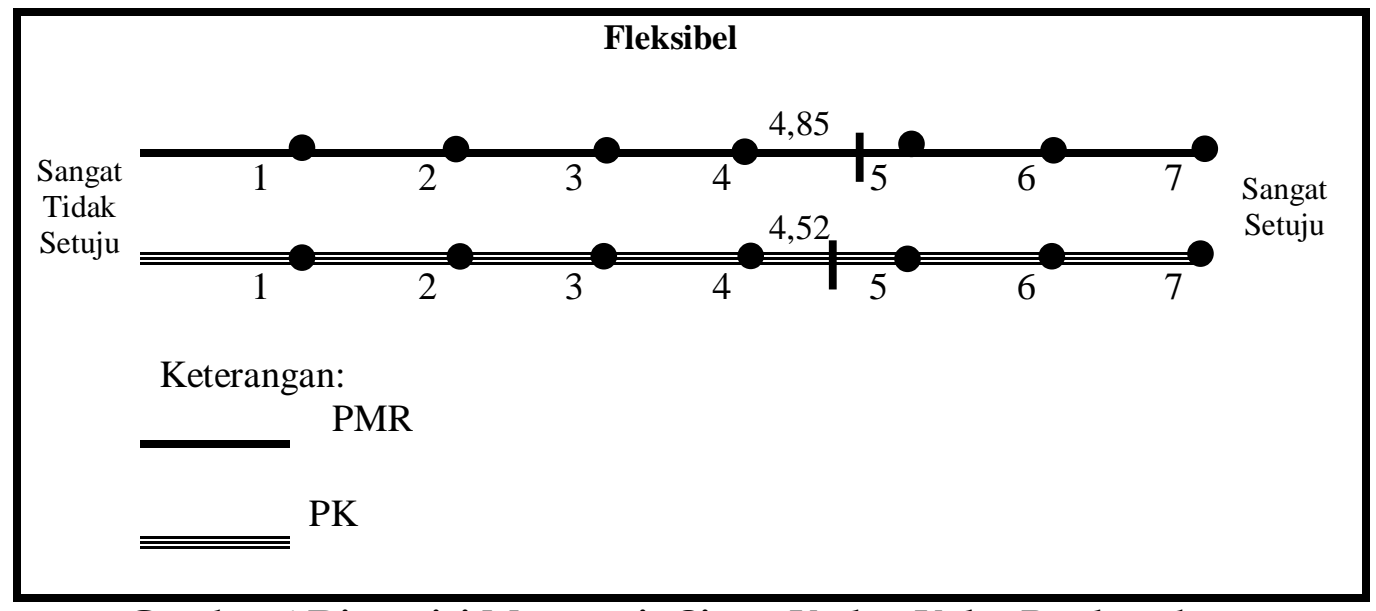

Gambar 4 Disposisi Matematis Siswa Kedua Kelas Berdasarkan Indikator Fleksibelitas

41 | Jurnal Pendidikan Matematika dan Matematika Vol. I No. 01 Februari 2019 
Pada Gambar 4 diperoleh bahwa fleksibelitas siswa yang memperoleh pembelajaran dengan pendekatan matematika realistik lebih tinggi yaitu 4,85 jika dibandingkan dengan rasa percaya diri siswa yang memperoleh pembelajaran dengan pendekatan konvensional, yaitu 4,52.

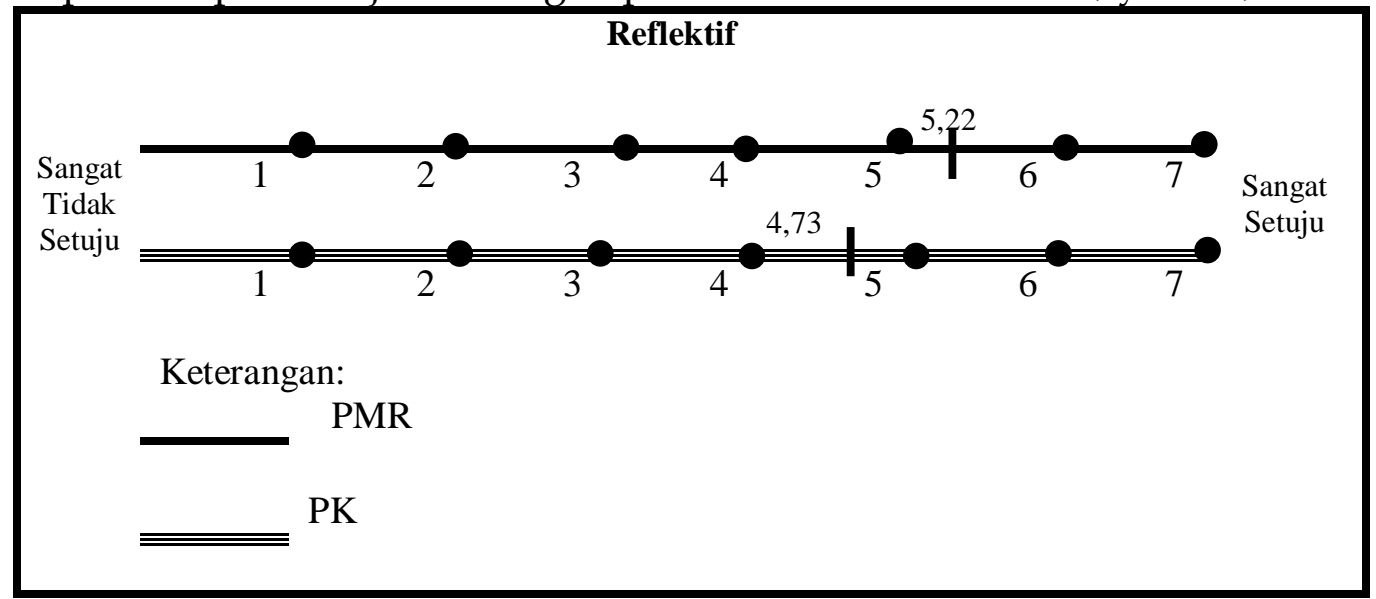

\section{Gambar 5 Disposisi Matematis Siswa Kedua Kelas Berdasarkan Indikator Reflektif}

Pada Gambar 5 diperoleh bahwa reflektif siswa yang memperoleh pembelajaran dengan pendekatan matematika realistik lebih tinggi yaitu 5,22 jika dibandingkan dengan rasa percaya diri siswa yang memperoleh pembelajaran dengan pendekatan konvensional, yaitu 4,73.

\section{KESIMPULAN DAN SARAN}

Ditinjau secara keseluruhan maupun berdasarkan tiap indikator disposisi matematis siswa yang memperoleh pembelajaran dengan pendekatan matematika realistik lebih baik secara signifikan daripada siswa yang memperoleh pembelajaran dengan pendekatan konvensional.

\section{DAFTAR RUJUKAN}

Ahmad Fauzan. (2003). Rute Belajar dalam RME: Suatu Arah untuk Pembelajaran Matematika. Makalah, disampaikan pada Seminar Nasional Pendidikan Matematika di Universitas Sanata Dharma Yogyakarta 27-28 Maret 2003

Bakker, A. (2004). Design Research in Statistic Education on Symbolizing and Computer Tools. Amersfoort: Wilco.

Kilpatrick, J., Swafford, J., \& Findell, B. (Eds). (2001). Adding it up: Helping Children Learn Mathematics. Washington, DC: National Academy Press.

Lestari, K. E. dan Mokhammad Ridwan Yudhanegara. 2015. Penelitian Pendidikan Matematika. Bandung: PT Refika Aditama.

Maxwell, K. (2001). Positive learning dispositions in mathematics. [Online]. 
http://www.education.auckland.ac.nz/uoa/fms/default/education $\angle$ docs/word/research/foed_paper/issue11/ACE_Paper_3_Issue_11. doc. [10 Desember 2017].

National Council of Teachers of Mathematics, (1989) Curriculum and Evaluation Standards for School Mathematics, Reston, Virginia.

Putra, A. K., Budiyono, \& Slamet, I. (2017, August). Mathematical disposition of hunior high school students viewed from learning styles. In AIP Conference Proceedings (Vol. 1868, No. 1, p. 050025). AIP Publishing.

Russefendi, E.T. (2010). Perkembangan Pendidikan Matematika. Jakarta: Universitas Terbuka.

Rahayu, R., \& Kartono, S. The Effect of Mathematical Disposition on PMRI toward Problem Solving Ability Based on Ideal Problem Solver.

Sumarmo, U. (2006), Berfikir Matematik Tingkat Tinggi: Apa, Mengapa, dan Bagaimana Dikembangkan pada Siswa Sekolah Menengah dan Mahasiswa Calon Guru. Makalah disajikan pada Seminar Pendidikan Matematika di Jurusan Matematika FMIPA Universitas Padjadjaran Tanggal 22 April 2006: tidak diterbitkan.

Usdiyana, D., Purniati, T., Yulianti, K., \& Harningsih, E. (2009). Meningkatkan kemampuan berpikir logis siswa SMP melalui pembelajaran matematika realistik. Jurnal Pengajaran MIPA, 13(1), 114.

Wiersma, W., \& Jurs, S. G. (2005). Research methods in education: An introduction. Boston, MA: Ally and Bacon. 